\title{
Inventory of mollusks from the estuary of the Paraíba River in northeastern Brazil
}

\author{
Silvio Felipe Barbosa Lima ${ }^{1 *}$, Rudá Amorim Lucena ${ }^{2}$, Galdênia Menezes Santos ${ }^{3}$,José Weverton Souza ${ }^{3}$, \\ Martin Lindsey Christoffersen ${ }^{2}$, Carmen Regina Guimarães ${ }^{4}$ \& Geraldo Semer Oliveira ${ }^{4}$ \\ ${ }^{1}$ Universidade Federal de Campina Grande, Unidade Acadêmica de Ciências Exatas e da Natureza, Centro de \\ Formação de Professores, Cajazeiras, PB, Brazil \\ ${ }^{2}$ Universidade Federal da Paraíba, Departamento de Sistemática e Ecologia, João Pessoa, PB, Brazil \\ ${ }^{3}$ Universidade Federal de Sergipe, Departamento de Ecologia, São Cristóvão, SE, Brazil \\ ${ }^{4}$ Universidade Federal de Sergipe, Departamento de Biologia, São Cristóvão, SE, Brazil \\ *Corresponding author: Silvio Felipe Lima, e-mail: sfblima@gmail.com
}

LIMA, S.F.B., LUCENA, R.A., SANTOS, G.M., SOUZA, J.W., CHRISTOFFERSEN, M.L., GUIMARÃES, C.R., OLIVEIRA, G.S. Inventory of mollusks from the estuary of the Paraíba River in northeastern Brazil. Biota Neotropica. 17(1): e20160239. http://dx.doi.org/10.1590/1676-0611-BN-2016-0239

\begin{abstract}
Coastal ecosystems of northeastern Brazil have important biodiversity with regard to marine mollusks, which are insufficiently studied. Here we provide an inventory of mollusks from two sites in the estuary of the Paraíba River. Mollusks were collected in 2014 and 2016 on the coast and sandbanks located on the properties of Treze de Maio and Costinha de Santo Antônio. The malacofaunal survey identified 12 families, 20 genera and 21 species of bivalves, 17 families, 19 genera and 20 species of gastropods and one species of cephalopod. Bivalves of the family Veneridae Rafinesque, 1815 were the most representative, with a total of five species. Gastropods of the family Littorinidae Children, 1834 had the greatest species richness. The most abundant species were: Neritina virginea (Linnaeus, 1758), Brachidontes exustus (Linnaeus, 1758), Crassostrea brasiliana (Lamarck, 1819), Cerithium atratum (Born, 1778), Anomalocardia brasiliana (Gmelin, 1791), Parvanachis obesa (C. B. Adams, 1845), Phrontis polygonata (Lamarck, 1822), Littoraria angulifera (Lamarck, 1822), L. flava (King, 1832), Tagelus plebeius (Lightfoot, 1786), Echinolittorina lineolata (d'Orbigny, 1840) and Iphigenia brasiliensis (Lamarck, 1818). The results show that the study area has considerable species richness of Mollusca, requiring environmental monitoring in the region mainly due to the economic importance of some species to the local population.
\end{abstract}

Keywords: Biodiversity, Mollusca, Gastropoda, Bivalvia, Cephalopoda, tropical coastal ecosystems.

\section{Inventário de moluscos do estuário do Rio Paraíba no nordeste do Brasil}

Resumo: Os ecossistemas costeiros do nordeste do Brasil têm uma importante biodiversidade de moluscos marinhos, a qual ainda é insuficientemente estudada. Este trabalho representa um inventário dos moluscos em duas localidades no estuário do Rio Paraíba. Moluscos foram coletados entre 2014 e 2016 na costa e área de restinga localizadas nas propriedades de Treze de Maio e Costinha de Santo Antônio. Este levantamento malacofaunístico identificou 12 famílias, 20 gêneros e 21 espécies de bivalves, 17 famílias, 19 gêneros e 20 espécies de gastrópodes e uma espécie de cefalópode. Os bivalves da família Veneridae Rafinesque, 1815 foram os mais representativos com um total de cinco espécies. Os gastrópodes da família Littorinidae Children, 1834 apresentaram a mais alta riqueza de espécies. As espécies mais abundantes foram: Neritina virginea (Linnaeus, 1758), Brachidontes exustus (Linnaeus, 1758), Crassostrea brasiliana (Lamarck, 1819), Cerithium atratum (Born, 1778), Anomalocardia brasiliana (Gmelin, 1791), Parvanachis obesa (C. B. Adams, 1845), Phrontis polygonata (Lamarck, 1822), Littoraria angulifera (Lamarck, 1822), L. flava (King, 1832), Tagelus plebeius (Lightfoot, 1786), Echinolittorina lineolata (d'Orbigny, 1840) e Iphigenia brasiliensis (Lamarck, 1818). Os resultados mostram que a área estudada tem uma considerável riqueza de espécies de Mollusca, necessitando de monitoramento ambiental, principalmente devido à importância econômica de algumas espécies para a população local.

Palavras-chave: Biodiversidade, Mollusca, Gastropoda, Bivalvia, Cephalopoda, ecossistemas costeiros tropicais. 


\section{Introduction}

The coast of Brazil has a considerable diversity of marine ecosystems (Amaral \& Jablonski 2005, MMA 2010) and significant species richness with regard to invertebrates living in a wide variety of intertidal and sublittoral environments (Amaral \& Jablonski 2005, Amaral et al. 2006, 2006-2012, Rios 2009). However, the biodiversity of invertebrates, especially mollusks remains poorly sampled and insufficiently researched in shallow waters of northeastern Brazil (Barroso et al. 2013, Cunha et al. 2016) Underestimated knowledge on the aspects of the biodiversity of Mollusca in northeastern Brazil has been demonstrated based on the discovery of ecological interactions (Queiroz et al. 2011, 2013, Lima et al. 2016a), records of occurrence and the description of new species (Barroso et al. 2013, Barros et al. 2015, Lima \& Guimarães 2015, Cunha et al. 2016, Lima et al. 2013, 2016b,c Lima \& Christoffersen 2016).

The state of Paraíba (northeastern Brazil) has approximately $138 \mathrm{~km}$ of coastline (De Assis et al. 2012) and a considerable variety of marine ecosystems and environments (e.g., mangroves, estuarine habitats, diverse reef formations, rocky beaches, sandy beaches and tide pools) (Melo et al. 2006, Araújo et al. 2008, De Assis et al. 2012, Duarte et al. 2014, 2015, Lima et al. 2014, Medeiros et al. 2016). The biodiversity of marine invertebrates (mainly mollusks and polychaetes) in this coastal area has been increasingly studied (Duarte et al. 2014, 2015, Santos et al. 2010, 2014, Lomônaco et al. 2011, De Assis et al. 2012, Brito et al. 2013, Fukuda et al. 2013, Paresque \& Nogueira 2014, Lima et al. 2014, Prata et al. 2014, Lucena et al. 2015, Lima \& Christoffersen 2016, Paresque et al. 2014, 2016), however, the mollusk diversity of large areas, such as basin of the Paraiba River remains unknown.

The marine zone surrounding the Treze de Maio and Costinha de Santo Antônio properties in the municipality of Lucena (state of Paraíba) is under the influence of abiotic and biotic factors of the Atlantic Ocean as well as the estuary of the Paraíba River. Part of the area located on these properties will be allocated to the implementation of a shipyard, so it is of fundamental importance to generate knowledge on the composition of marine mollusks in the area for environmental management and conservation strategies, including monitoring purposes.
The aim of this study was to provide a malacofaunistic survey from the estuary of the Paraíba River in the state of Paraíba (northeastern Brazil).

\section{Material and Methods}

\section{Study site}

The studied area is located on the properties of Treze de Maio and Costinha de Santo Antônio (0658'17.59'S, 3451'47.19”W), which are within the area of influence of the estuary of the Paraíba River in the city of Lucena, state of Paraíba, northeastern Brazil. The surrounding coastal environment is characterized by mangrove forests (Sassi 1991) in non-urbanized areas and a large sand bank that is exposed at low tide (personal observations). The study area is under the influence of the Atlantic Ocean (Medeiros et al. 2016) and the main tributaries on the right (Sanhauá, Tambiá and Mandacaru Rivers) and left (Paroeira, Tiririm, Ribeira and Guia Rivers) margins, which carry sediment, nutrients, domestic sewage and industrial waste into the region (Sassi 1991, Marcelino et al. 2005). The area is not under the direct influence of wave impacts and has a beach with flat to slightly steep areas (personal observations), with predominantly sandy-muddy (Sassi 1991) (Figure 1).

\subsection{Data collection and analysis}

Mollusks were collected in two campaigns (June 2014 and February 2016) in a region planned for the implementation of a shipyard on the Treze de Maio and Costinha de Santo Antônio properties and adjacent areas. Collections were carried out at low tide through active searches lasting approximately two hours per day. During the first campaign, trawls were also employed for the collection of cephalopods. During the second campaign (February $15^{\text {th }}$ to $19^{\text {th }}, 2016$ ), mollusks were manually collected at low tide in the supratidal to subtidal regions located along the coastal area and adjacent sandbanks of the properties. A total of eight samples of unconsolidated substrates were randomly collected from the shallow subtidal region in these areas at a depth of about $1 \mathrm{~m}$ : four collection sites along the coastal area of the properties (Figure 1B - dashed yellow line of
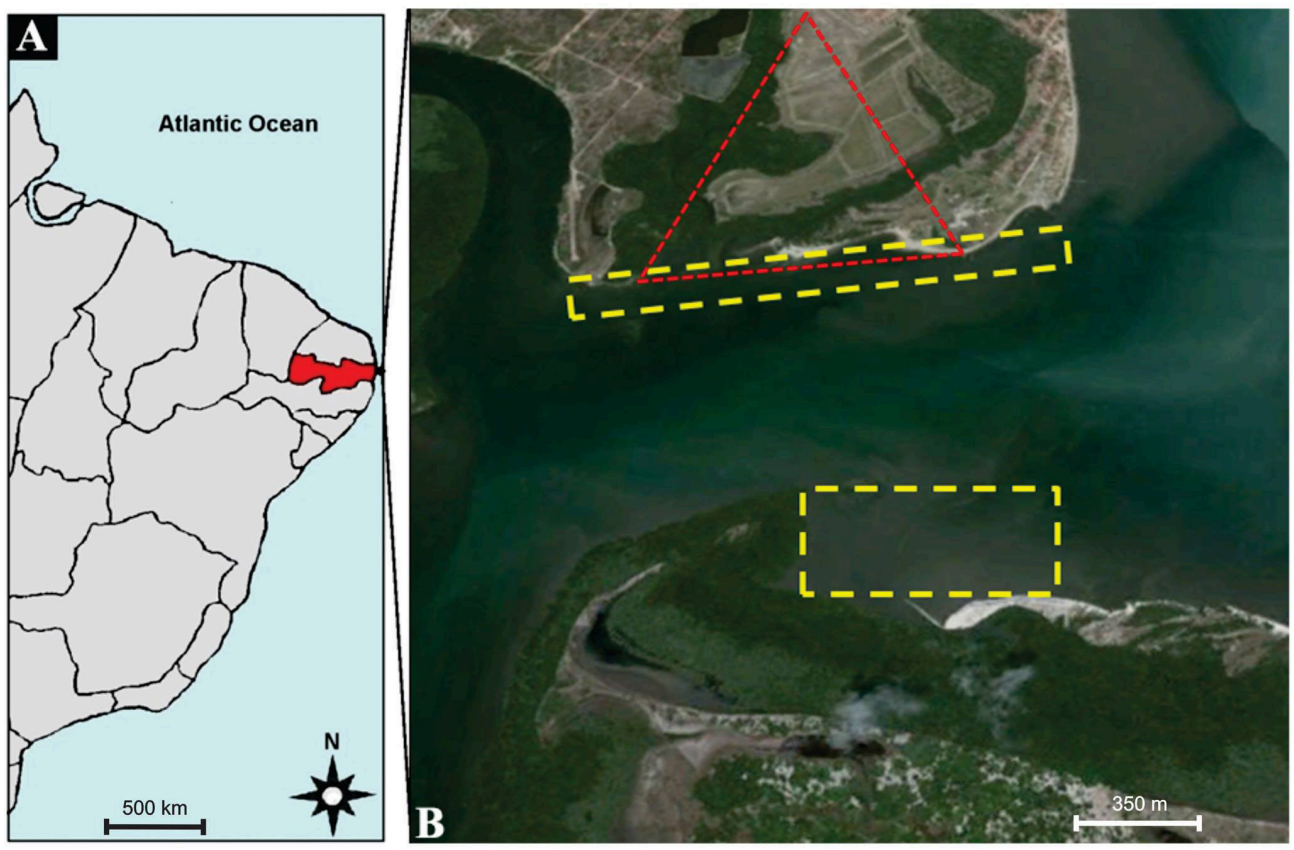

Figure 1. (A) Map of Brazilian coast and state of Paraíba (highlighted in red); (B) Photo of estuary of Paraíba River showing Treze de Maio and Costinha de Santo Antônio properties (upper area) and adjacent region (dashed red: construction area of shipyard; dashed yellow: collection area). 
upper area) and four collection sites on the adjacent sandbanks (Figure 1B - dashed yellow line of lower area).

All mollusks and substrates collected were fixed in 5\% formalin. In the laboratory, the substrates were processed through sieves (5 to $2 \mathrm{~mm}$ in mesh size) to separate mollusks. All specimens were preserved in 70\% ethanol. The classification of Mollusca was based on the World Register of Marine Species (WORMS). The identification at the specific level was mainly based on Rios (2009), Tunnell Jr. et al. (2010) and Redfern (2013).

Most of the material analyzed is deposited and available for study at the "Coleção de Invertebrados Paulo Young, Departamento de Sistemática e Ecologia, Universidade Federal da Paraíba (UFPB MOLL), João Pessoa, Paraíba, Brazil".

\section{Results}

A total of 1978 specimens from three classes, 14 orders, 31 families, 39 genera and 40 species were recorded for the estuarine region surrounding the Treze de Maio and Costinha de Santo Antônio properties (Table 1). This total includes one family and one species of cephalopod, 12 families, 20 genera and 21 species of bivalve and 18 families, 19 genera and 20 species of gastropod (Table 1; Figures 2-13).

Carditida, Myida, Anaspidea, Cephalaspidea, Cycloneritimorpha and Myopsida were each represented by one species, whereas Arcida, Lucinida and Mytilida were each represented by two species. Cardiida, Venerida, Littorinimorpha and Neogastropoda were the most representative groups,

Table 1. Checklist of Mollusca from estuary of Paraíba River on surrounding Treze de Maio and Costinha de Santo Antônio properties. (-) species addressed in another study; (--) species observed in the environment.

\begin{tabular}{|c|c|c|c|c|c|}
\hline Class & Order & Family & $\begin{array}{r}\text { Species } \\
\end{array}$ & Spec. & Voucher \\
\hline \multirow{21}{*}{ Bivalvia } & Arcida & Arcidae & Anadara chemnitzi (Philippi, 1851) & 01 & 3553 \\
\hline & Arcida & Arcidae & Lunarca ovalis (Bruguière, 1789) & 18 & 3554 \\
\hline & Cardiida & Donacidae & Iphigenia brasiliensis (Lamarck, 1818) & 26 & 3555 \\
\hline & Cardiida & Cardiidae & Dallocardia muricata (Linnaeus, 1758) & 06 & 3556 \\
\hline & Cardiida & Tellinidae & Macoma constricta (Bruguière, 1792) & 17 & 3557 \\
\hline & Cardiida & Tellinidae & Eurytellina lineata (Turton, 1819) & 12 & 3558 \\
\hline & Cardiida & Solecurtidae & Tagelus plebeius (Lightfoot, 1786) & 52 & 3559 \\
\hline & Carditida & Crassatellidae & Crassinella sp. & 01 & 3560 \\
\hline & Lucinida & Lucinidae & Divalinga quadrisulcata (d'Orbigny, 1846) & 03 & 3561 \\
\hline & Lucinida & Lucinidae & Phacoides pectinatus (Gmelin, 1791) & 11 & 3562 \\
\hline & Myida & Myidae & Sphenia fragilis (H. Adams \& A. Adams, 1854) & 01 & 3563 \\
\hline & Mytilida & Mytilidae & Mytella charruana (d’Orbigny, 1842) & 12 & 3564 \\
\hline & Mytilida & Mytilidae & Brachidontes exustus (Linnaeus, 1758) & 238 & 3565 \\
\hline & Ostreida & Ostreidae & Crassostrea brasiliana (Lamarck, 1819) & 207 & 3566 \\
\hline & Ostreida & Ostreidae & Ostrea cf. puelchana d’Orbigny, 1842 & 01 & - \\
\hline & Venerida & Veneridae & Anomalocardia brasiliana (Gmelin, 1791) & 149 & 3567 \\
\hline & Venerida & Veneridae & Chione cancellata (Linnaeus, 1767) & 01 & 3624 \\
\hline & Venerida & Veneridae & Chione subrostrata (Lamarck, 1818) & 18 & 3625 \\
\hline & Venerida & Veneridae & Lamelliconcha circinata (Born, 1778) & 03 & 3626 \\
\hline & Venerida & Veneridae & Tivela mactroides (Born, 1778) & 06 & 3627 \\
\hline & Unassigned & Mactridae & Mulinia cleryana (d'Orbigny, 1846) & 08 & 3628 \\
\hline \multirow{21}{*}{ Gastropoda } & Anaspidea & Aplysiidae & Aplysia dactylomela Rang, 1828 & 03 & -- \\
\hline & Cephalaspidea & Bullidae & Bulla striata Bruguière, 1792 & 12 & 3630 \\
\hline & Cycloneritimorpha & Neritidae & Neritina virginea (Linnaeus, 1758) & 610 & 3631 \\
\hline & Littorinimorpha & Cassidae & Semicassis granulata (Born, 1778) & 01 & 3632 \\
\hline & Littorinimorpha & Littorinidae & Littoraria angulifera (Lamarck, 1822) & 54 & 3633 \\
\hline & Littorinimorpha & Littorinidae & Littoraria flava (King, 1832) & 37 & 3634 \\
\hline & Littorinimorpha & Littorinidae & Echinolittorina lineolata (d'Orbigny, 1840) & 36 & 3635 \\
\hline & Littorinimorpha & Naticidae & Stigmaulax cayennensis (Récluz, 1850) & 02 & 3636 \\
\hline & Neogastropoda & Columbellidae & Parvanachis obesa (C. B. Adams, 1845) & 128 & 3637 \\
\hline & Neogastropoda & Melongenidae & Pugilina tupiniquim Abbate \& Simone, 2015 & 15 & 3638 \\
\hline & Neogastropoda & Muricidae & Stramonita brasiliensis Claremont \& D. G. Reid, 2011 & 09 & 3639 \\
\hline & Neogastropoda & Muricidae & Chicoreus brevifrons (Lamarck, 1822) & 01 & 3640 \\
\hline & Neogastropoda & Nassariidae & Phrontis polygonata (Lamarck, 1822) & 86 & 3641 \\
\hline & Neogastropoda & Olivellidae & Olivella minuta (Link, 1807) & 02 & 3642 \\
\hline & Neogastropoda & Turbinellidae & Turbinella laevigata Anton, 1838 & 02 & 3643 \\
\hline & Unassigned & Calliostomatidae & Calliostoma adspersum (Philippi, 1851) & 01 & 3644 \\
\hline & Unassigned & Cerithiidae & Cerithium atratum (Born, 1778) & 169 & 3645 \\
\hline & Unassigned & Cerithiidae & Bittiolum varium (Pfeiffer, 1840) & 01 & 3646 \\
\hline & Unassigned & Ellobiidae & Melampus coffea (Linnaeus, 1758) & 15 & 3647 \\
\hline & Unassigned & Epitoniidae & not identified & 01 & - \\
\hline & Unassigned & Trochidae & Tegula viridula (Gmelin, 1791) & 01 & 3648 \\
\hline Cephalopoda & Myopsida & Loliginidae & Lolliguncula brevis (Blainville, 1823) & 01 & - \\
\hline
\end{tabular}




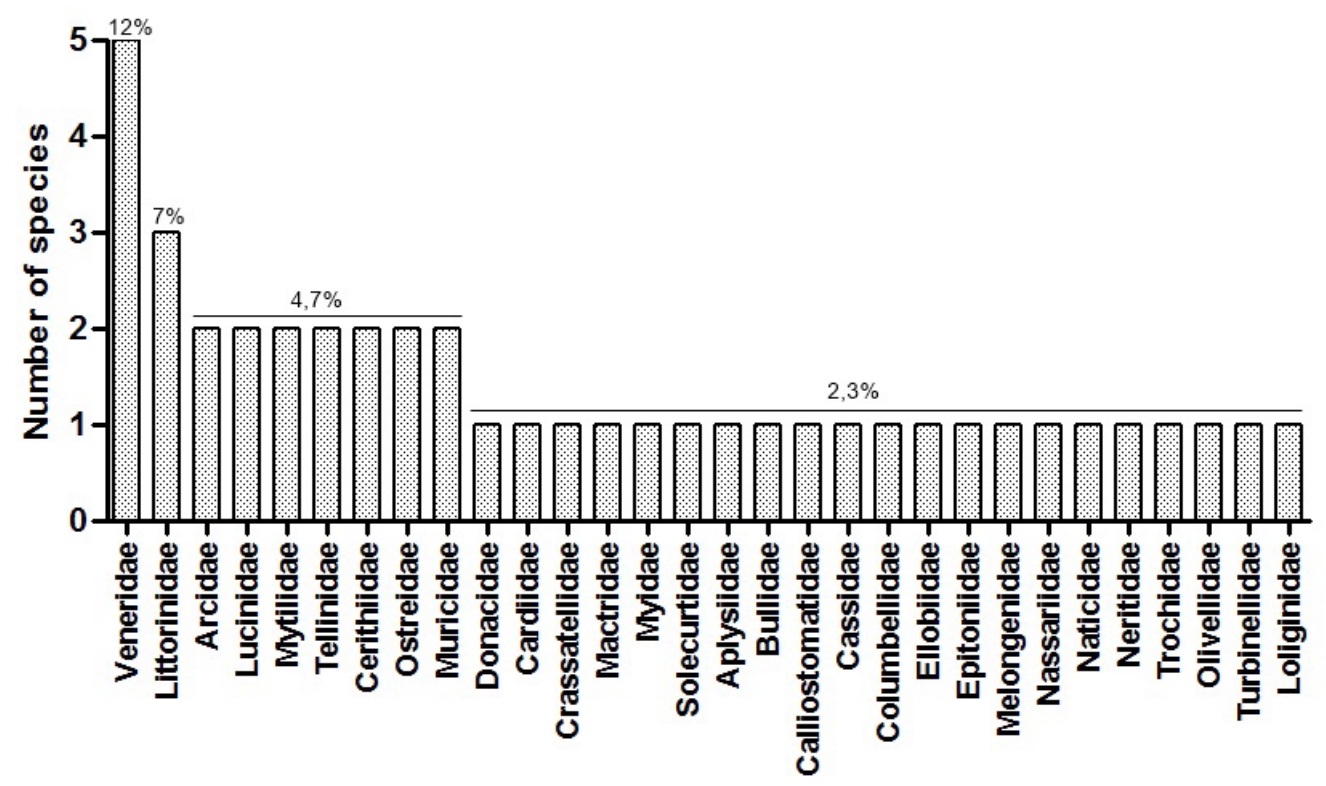

\section{Families of Mollusca}

Figure 2. Number of species and relative frequency of mollusk families collected from estuary of Paraíba River on surrounding Treze de Maio and Costinha de Santo Antônio properties.

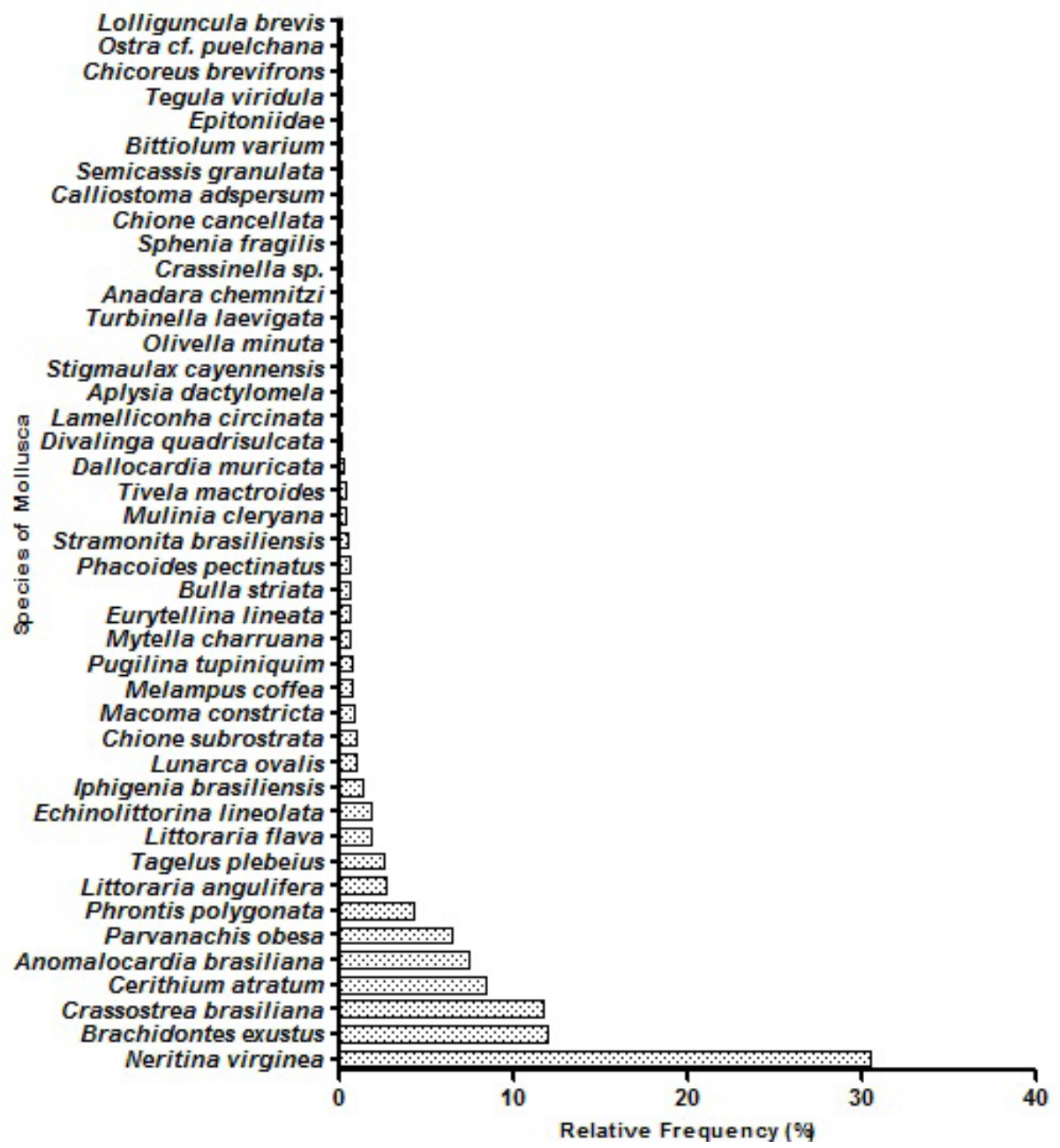

Figure 3. Species and relative frequency of mollusks collected from estuary of Paraíba River on surrounding Treze de Maio and Costinha de Santo Antônio properties. 


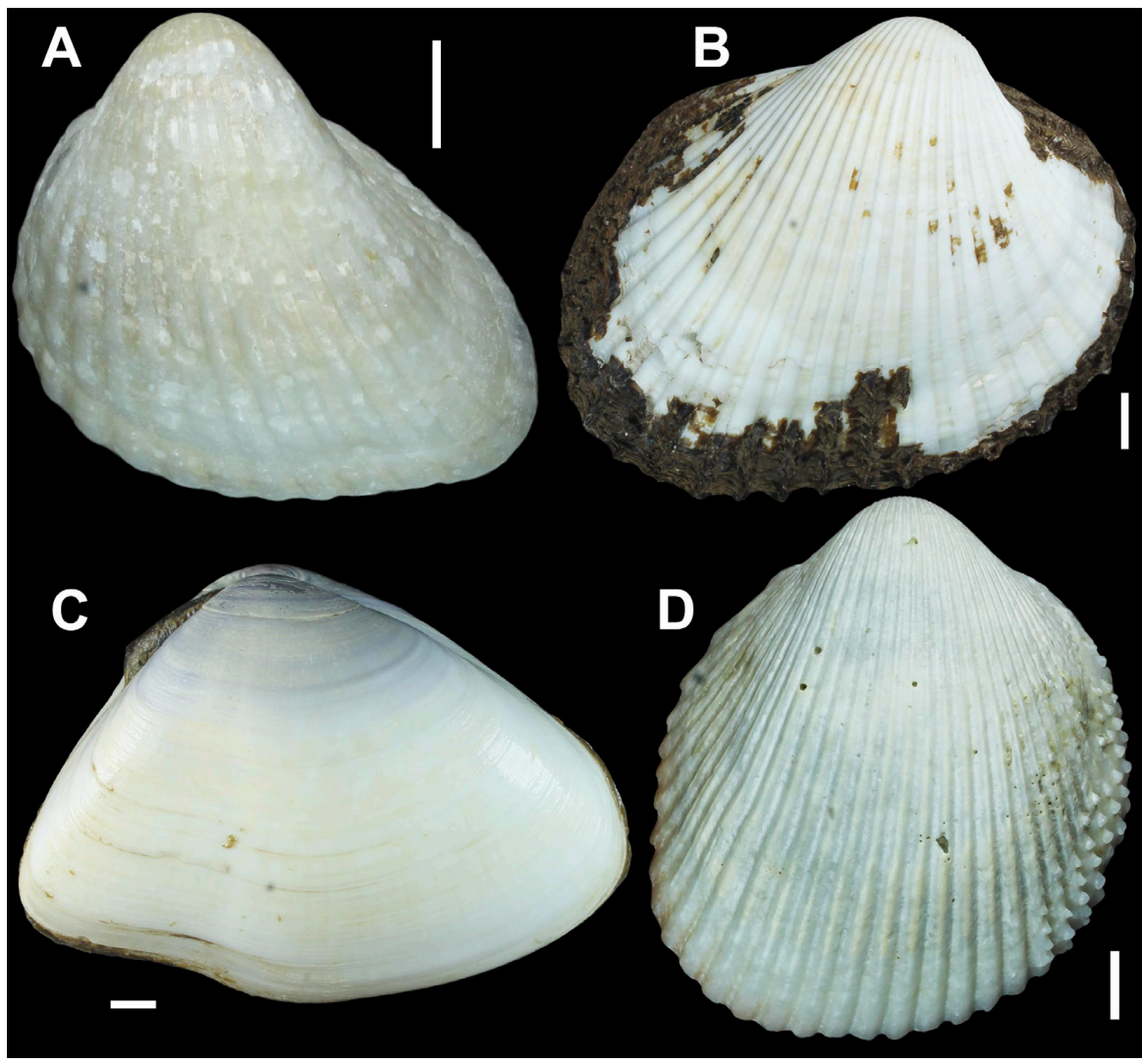

Figure 4. External view of shell of the bivalves collected from estuary of Paraíba River on surrounding Treze de Maio and Costinha de Santo Antônio properties: (A) Anadara chemnitzi, (B) Lunarca ovalis, (C) Iphigenia brasiliana, (D) Dallocardia muricata. Scale bars: $5 \mathrm{~mm}$.

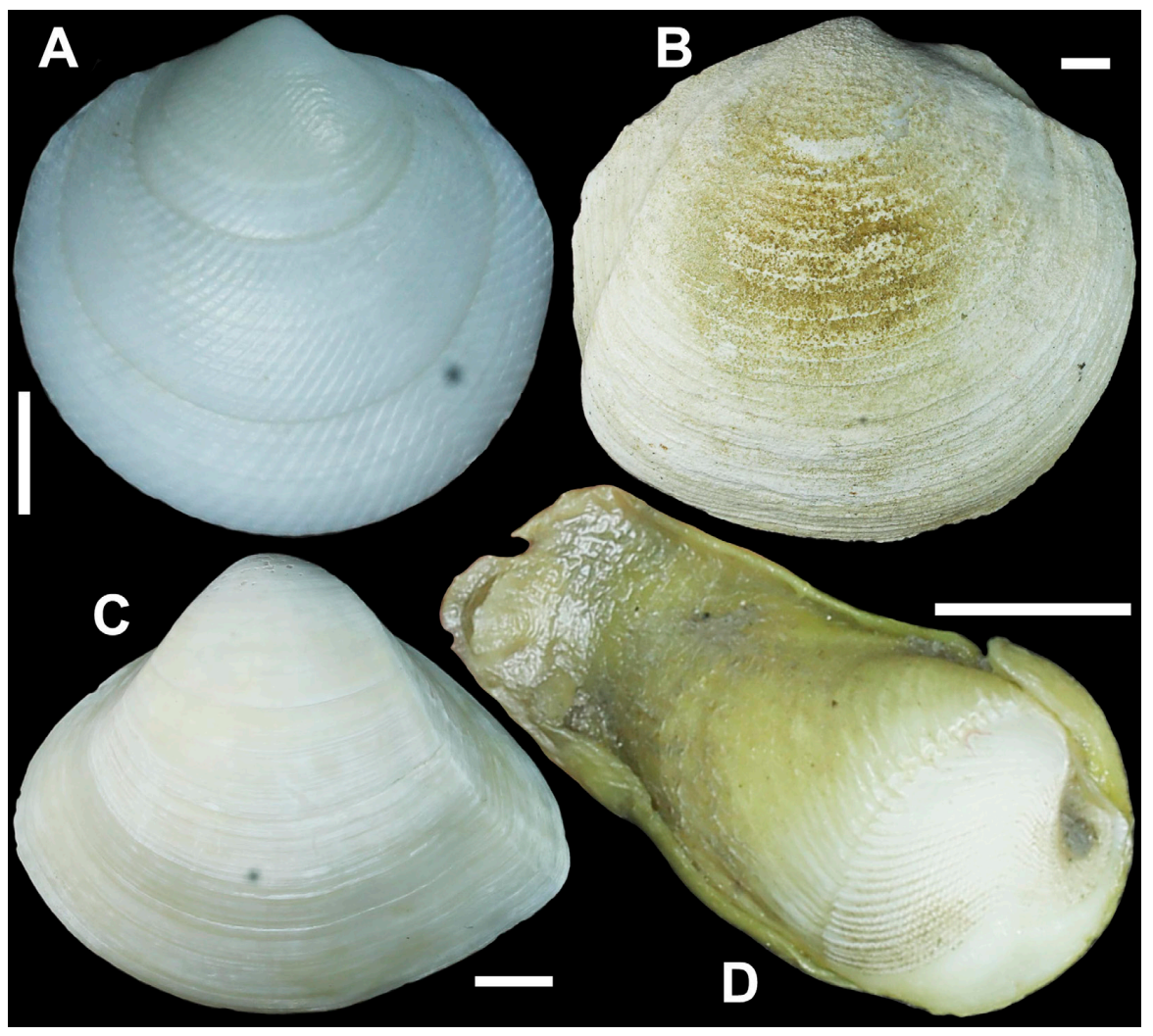

Figure 5. External view of shell of the bivalves collected from estuary of Paraíba River on surrounding Treze de Maio and Costinha de Santo Antônio properties: (A) Divalinga quadrisulcata, (B) Phacoides pectinatus, (C) Mulinia cleryana, (D) Sphenia fragilis. Scale bars: $5 \mathrm{~mm}$. 


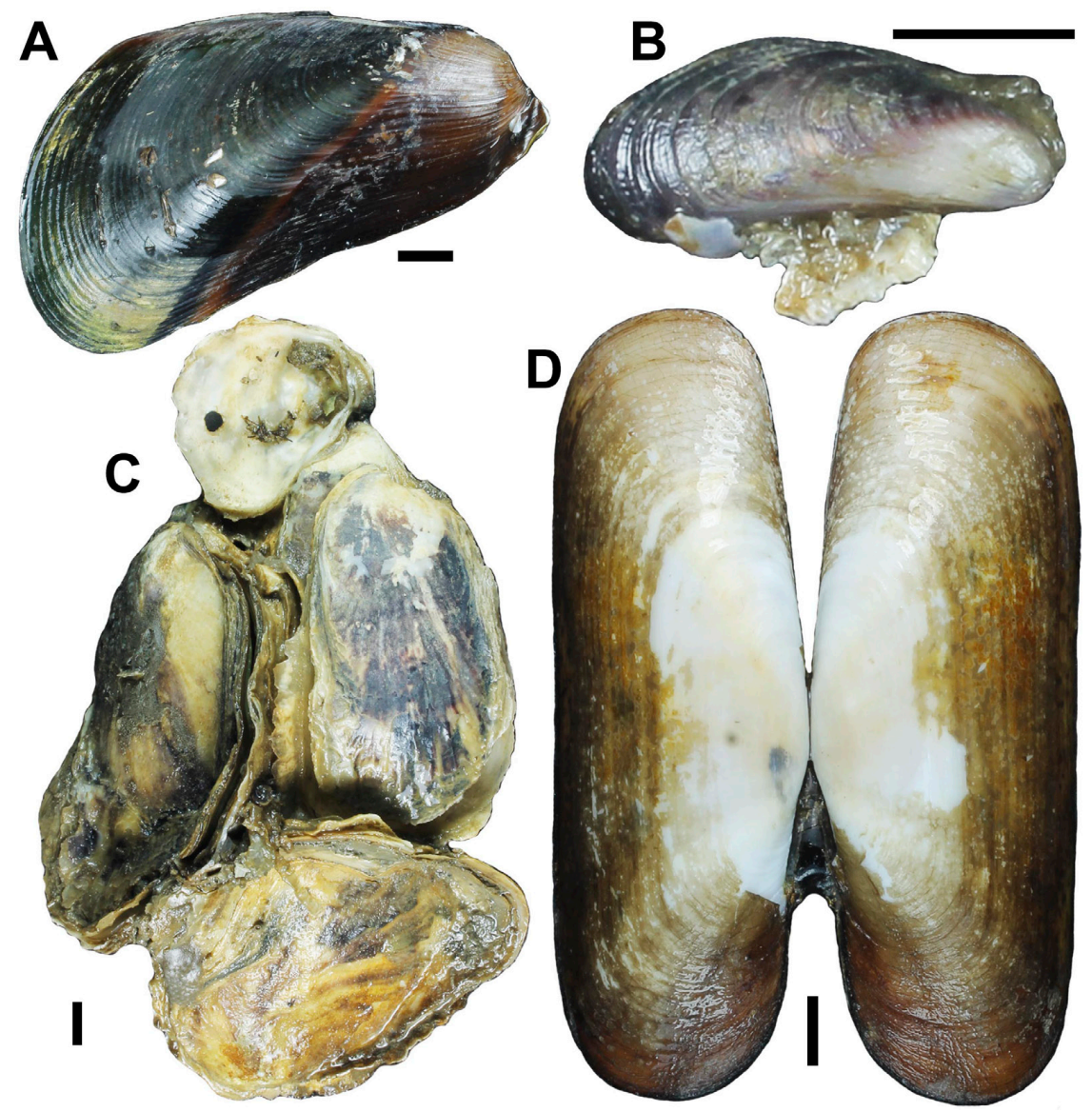

Figure 6. External view of shell of the bivalves collected from estuary of Paraíba River on surrounding Treze de Maio and Costinha de Santo Antônio properties: (A) Mytella charruana, (B) Brachidontes exustus, (C) Crassostrea brasiliana, (D) Tagelus plebeius. Scale bars: $5 \mathrm{~mm}$.

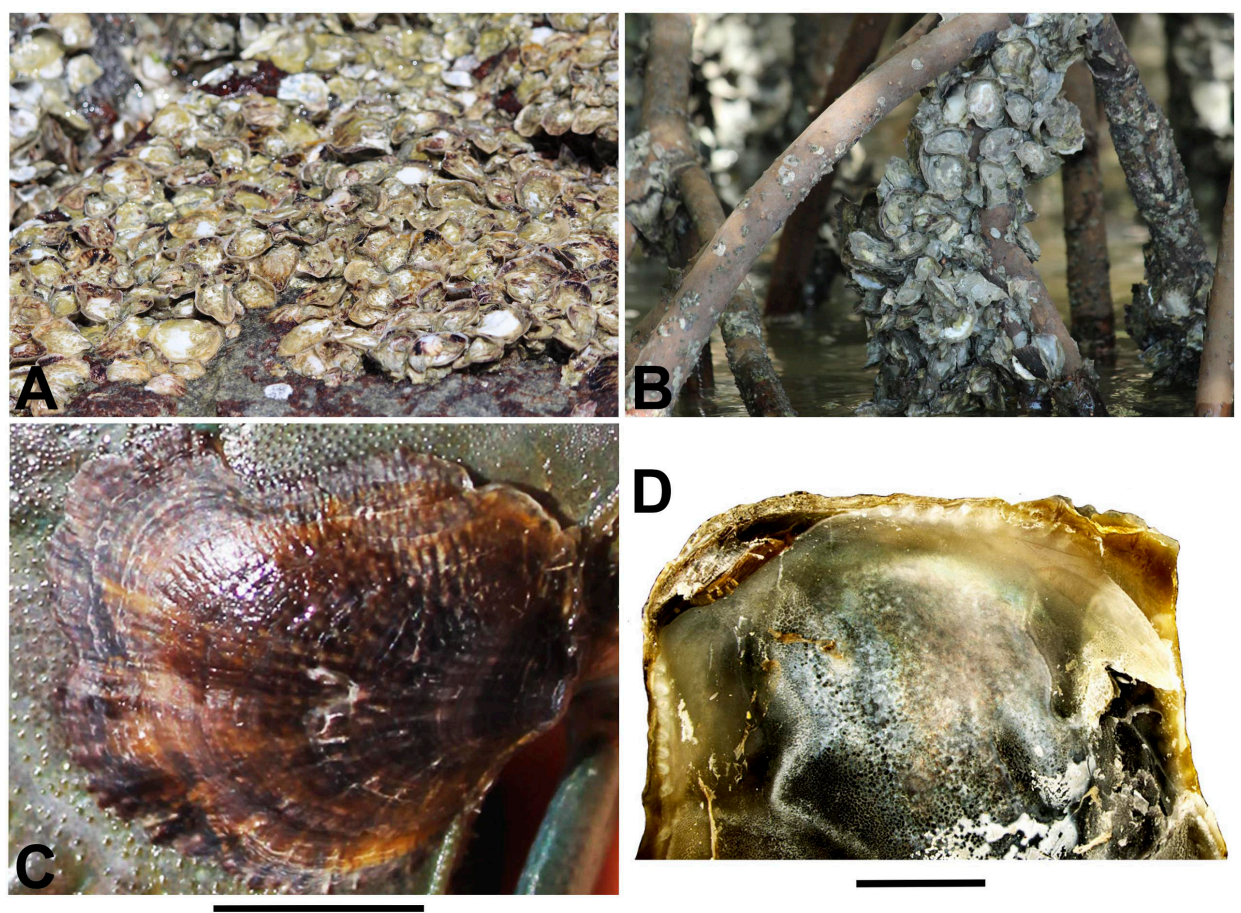

Figure 7. Crassostrea brasiliana on rock bottoms (A) and mangrove roots (B) and Ostrea cf. puelchana in external view of shell, left valve (C) and internal view of shell, left valve (D) from estuary of Paraíba River on surrounding Treze de Maio and Costinha de Santo Antônio properties. Scale bars: C. $1 \mathrm{~cm}$, D. 5 mm. 


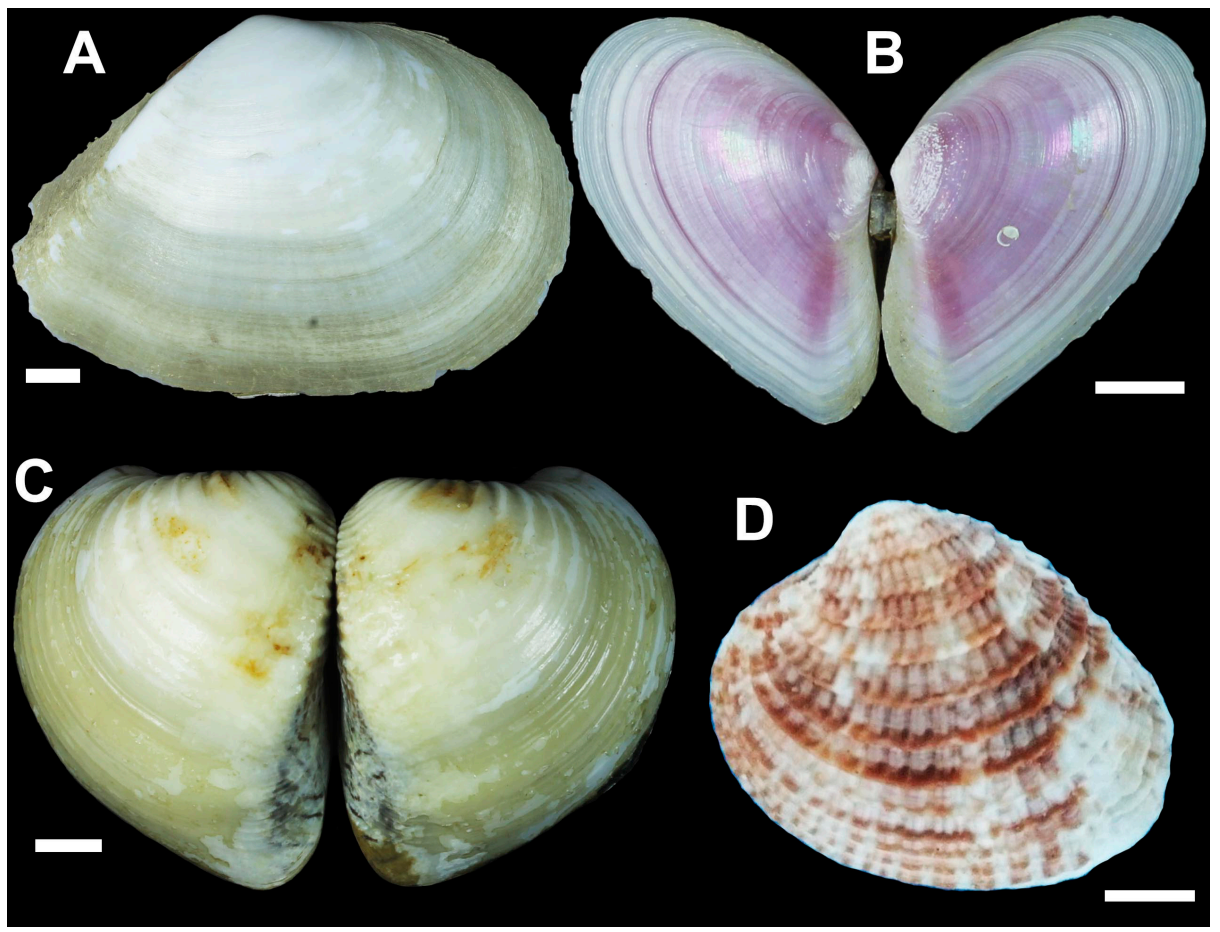

Figure 8. External view of shell of the bivalves collected from estuary of Paraíba River on surrounding Treze de Maio and Costinha de Santo Antônio properties: (A) Macoma constricta, (B) Eurytellina lineata, (C) Anomalocardia brasiliana, (D) Chione cancellata. Scale bars: $5 \mathrm{~mm}$.

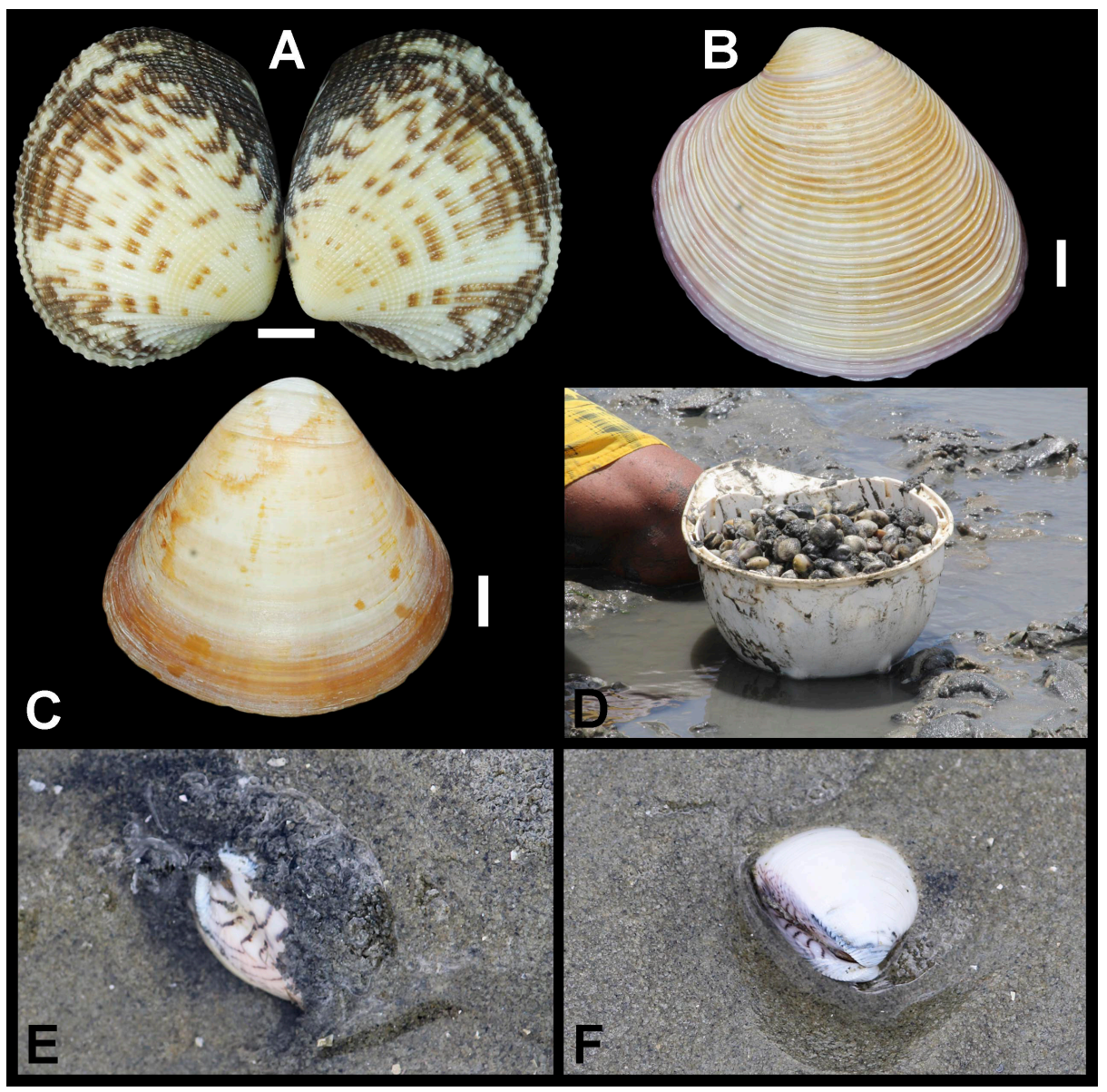

Figure 9. External view of shell of the bivalves collected from estuary of Paraíba River on surrounding Treze de Maio and Costinha de Santo Antônio properties: (A) Chione subrostrata, (B) Lamelliconcha circinata, (C) Tivela mactroides, (D-F) Anomalocardia brasiliana (length: about $31 \mathrm{~mm}$ ). Scale bars: A-C. $5 \mathrm{~mm}$. 


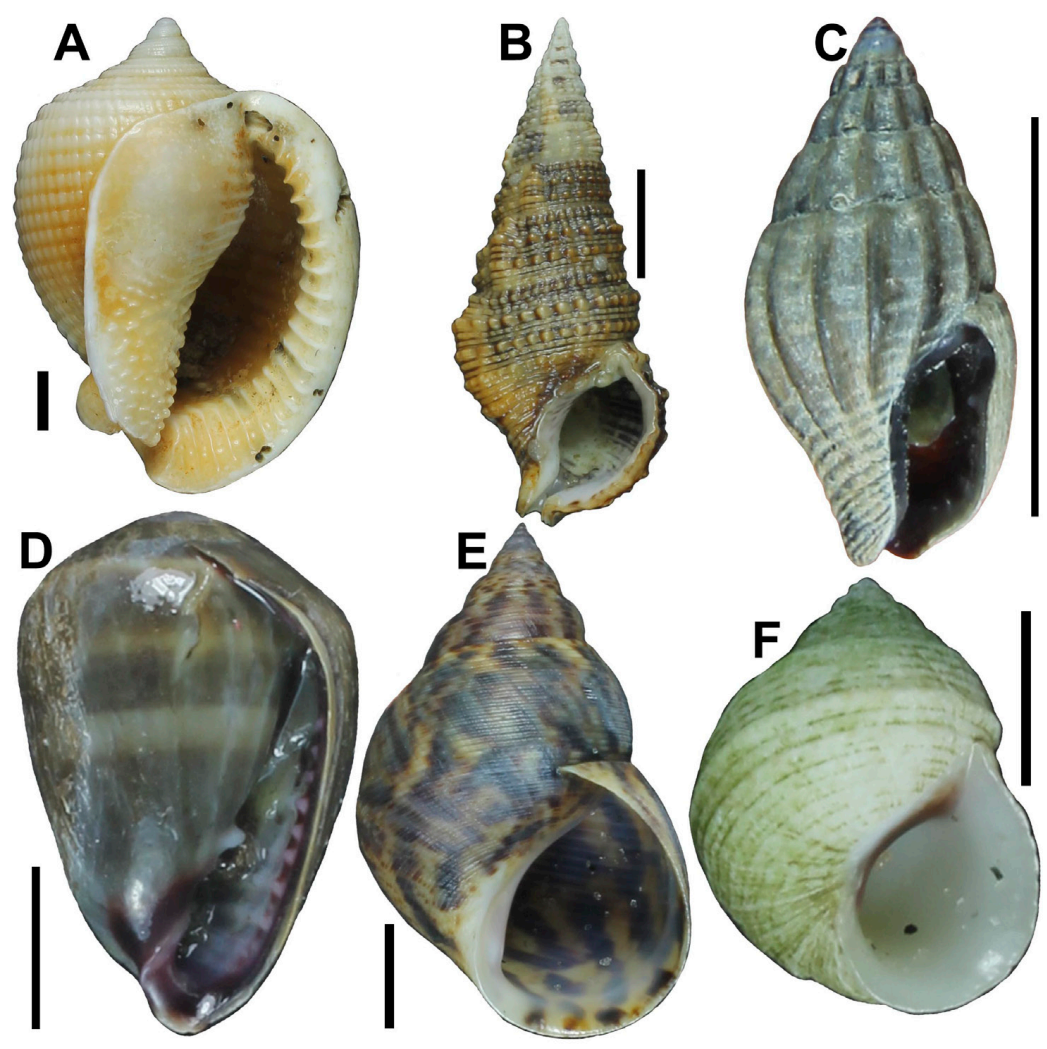

Figure 10. Ventral view of shell of the gastropods collected from estuary of Paraíba River on surrounding Treze de Maio and Costinha de Santo Antônio properties: (A) Semicassis granulata, (B) Cerithium atratum, (C) Parvanachis obesa, (D) Melampus coffea, (E) Littoraria angulifera, (F) L. flava. Scale bars: 5 mm.

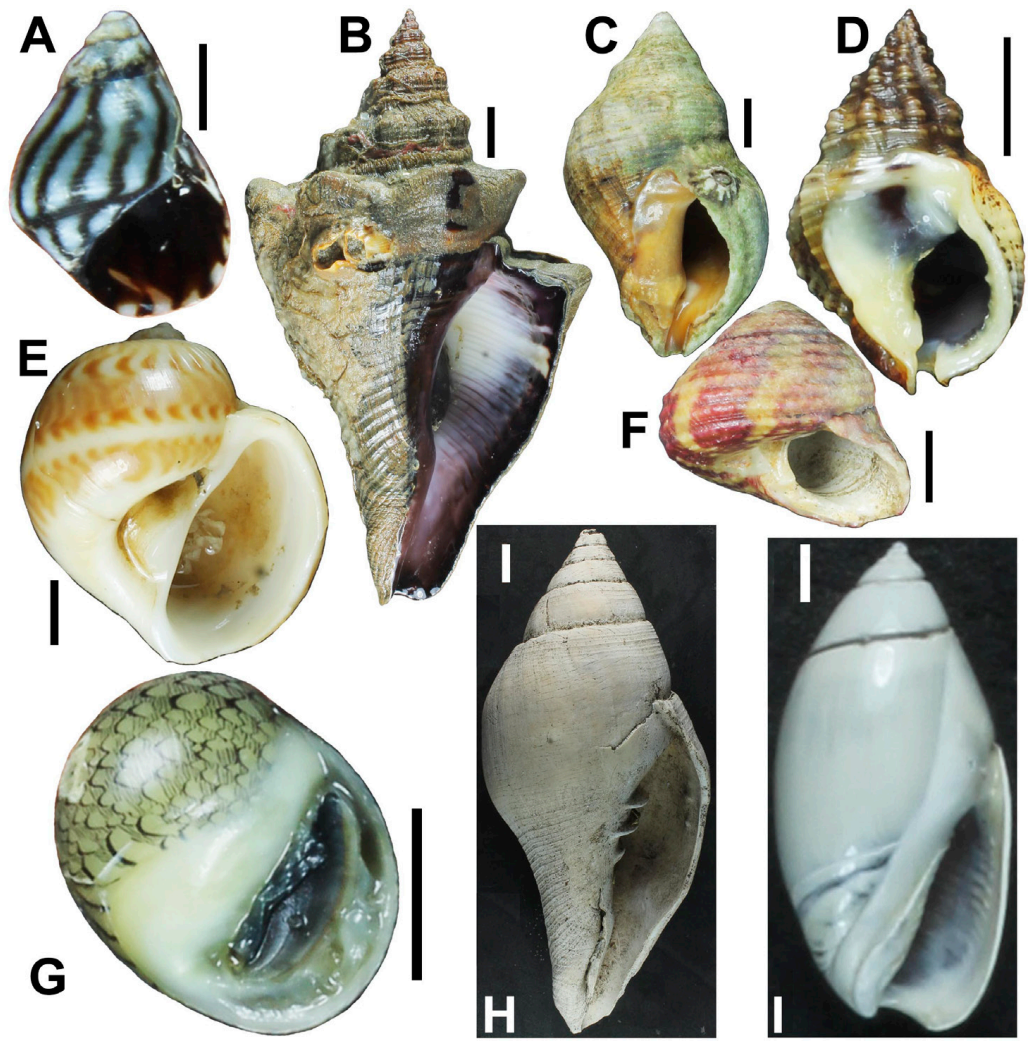

Figure 11. Ventral view of shell of the gastropods collected from estuary of Paraíba River on surrounding Treze de Maio and Costinha de Santo Antônio properties: (A) Echinolittorina lineolata, (B) Pugilina tupiniquim, (C) Stramonita brasiliensis, (D) Phrontis polygonata, (E) Stigmaulax cayennensis, (F) Tegula viridula, (G) Neritina virginea, (H) Turbinella laevigata, (I) Olivella minuta. Scale bars: $5 \mathrm{~mm}$. 


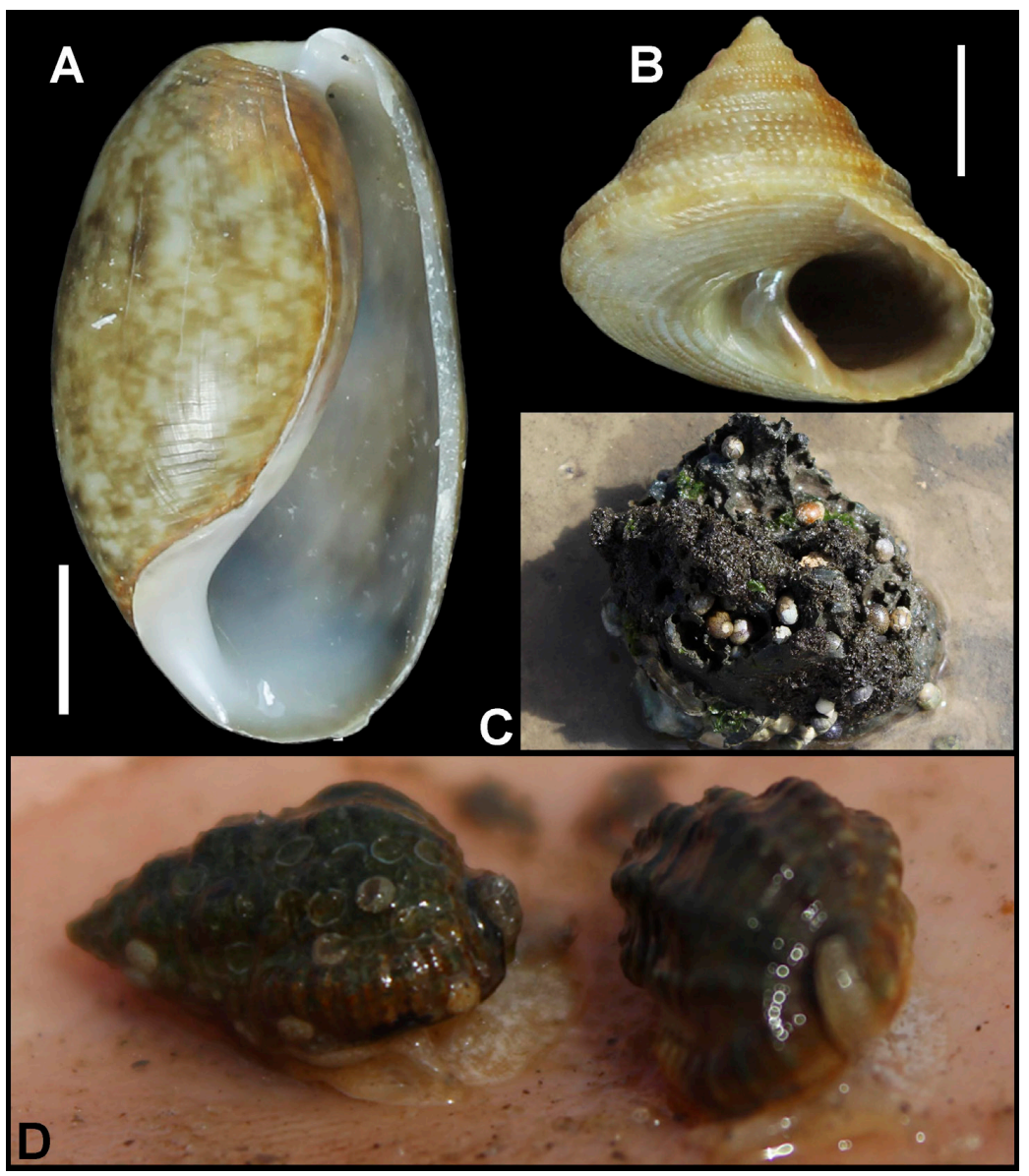

Figure 12. Ventral view of shell of the gastropods collected from estuary of Paraíba River on surrounding Treze de Maio and Costinha de Santo Antônio properties: (A) Bulla striata, (B) Calliostoma adspersum, (C) Neritina virginea (length: about $10 \mathrm{~mm}$ ), (D) Phrontis polygonata (length: about $11 \mathrm{~mm}$ ). Scale bars: A-B. $5 \mathrm{~mm}$.

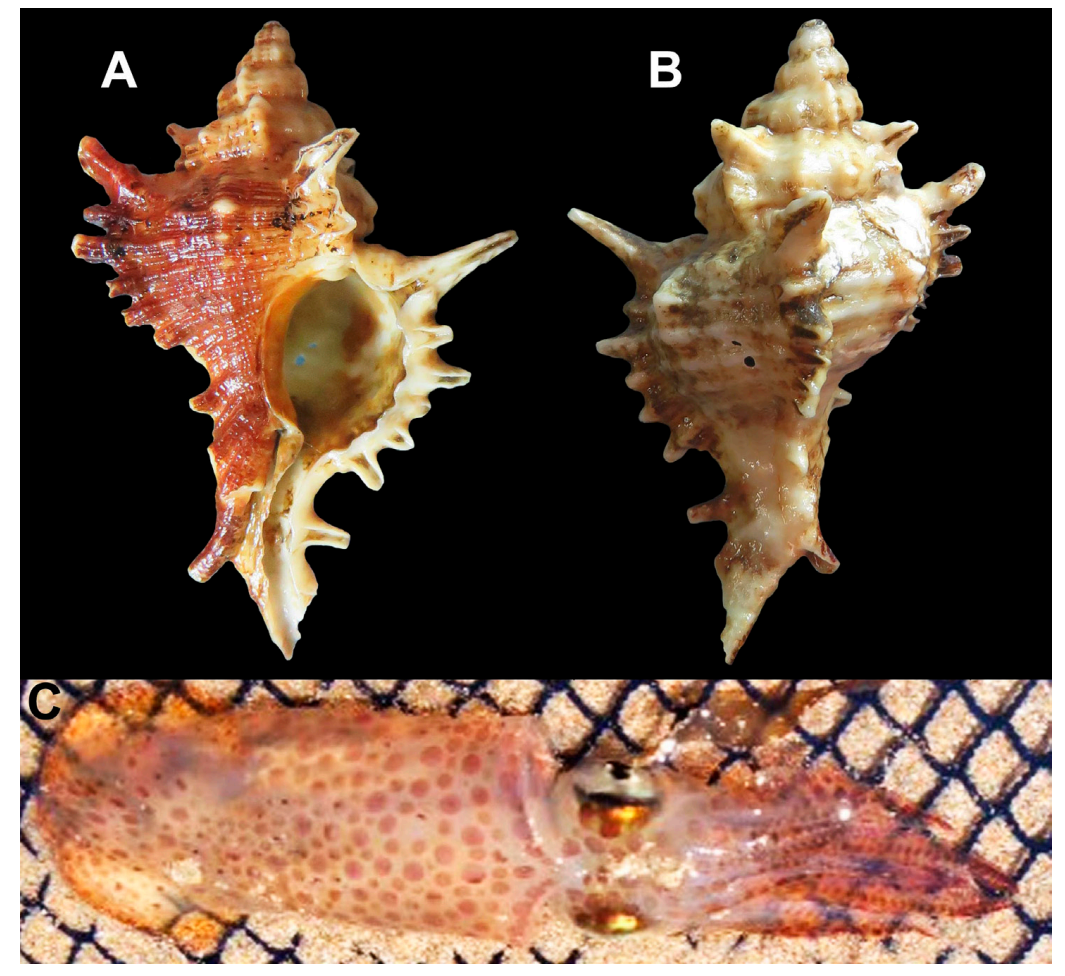

Figure 13. Ventral (A) and dorsal (B) view of shell of the gastropod Chicoreus brevifrons (length: $4.7 \mathrm{~cm}$ ) and dorsal view (C) of the cephalopod Lolliguncula brevis (length: about $10 \mathrm{~cm}$ ) collected from estuary of Paraíba River on surrounding Treze de Maio and Costinha de Santo Antônio properties. 
each with five to seven species and representing $35 \%$ of the mollusks recorded (Table 1; Figure 2). The family Mactridae and another six families of gastropods were not attributed to the order level based on the WORMS classification (Table 1). Veneridae (Venerida) showed the highest number of species (12\%), followed by Littorinidae (Littorinimorpha) $(7.1 \%)$ (Figure 2). Seven families were each represented by two species (Arcidae, Cerithiidae, Lucinidae, Muricidae, Mytilidae, Ostreidae and Tellinidae) (Table 1; Figure 2). The other families recognized in this study (e.g., Donacidae, Columbellidae and Loliginidae) were each represented by only one species (Table 1; Figure 2).

Except for the single specimen from Epitoniidae, all mollusks were identified at the specific level. The epitoniid sampled in this study is probably an undescribed species and will be addressed in another paper. Calliostoma adspersum (Philippi, 1851) and Chicoreus brevifrons (Lamarck, 1822) are formally recorded for the first time for the coast of Paraíba. Other species are not duly reported in the literature from the region, but are very abundant along the coast of Brazil to be considered new records for the state. No introduced or exotic mollusks were found in the area sampled.

In terms of abundance, bivalves Mytilidae [Brachidontes exustus (Linnaeus, 1758)], Ostreidae [Crassostrea brasiliana (Lamarck, 1819)] and Veneridae [Anomalocardia brasiliana (Gmelin, 1791)] as well as gastropods Neritidae [Neritina virginea (Linnaeus, 1758)], Columbellidae [Parvanachis obesa (C. B. Adams, 1845)] and Cerithiidae [Cerithium atratum (Born, 1778)] were the most numerous, together representing $76 \%$ of the total number of individuals (Table 1; Figures $2-3$ ).

\section{Discussion}

This survey is the first attempt to know the biodiversity of marine mollusks of the estuary of the Paraíba River. The species richness and composition of the region, including many species of economic value show the importance of this transitional aquatic environment in the northeastern Brazil. Information on the shell morphology, geographical distribution and ecological aspects of the species listed here were described by Rios (2009), Tunnell Jr. et al. (2010) and Redfern (2013).

Previous malacofaunal surveys have been conducted in coastal ecosystems of Brazil. Ourives et al. (2011) listed 94 gastropod species for Camamu Bay in the state of Bahia (northeastern Brazil). Barroso et al. (2013) found 47 species of mollusks from the Grande Island estuarine complex in the state of Ceará (northeastern Brazil). Longo et al. (2014) recognized 62 gastropod species associated with the brown algae Sargassum sp. in the São Sebastião Channel on the northern coast of the state of São Paulo (southeastern Brazil). Tallarico et al. (2014) provide a list of 52 bivalve species inhabiting the intertidal and subtidal zones of the São Sebastião Channel. Duarte et al. (2014) found 65 mollusk species in three shallow-water reef habitats along the coast of the state of Paraíba. Duarte et al. (2015) identified 18 species of gastropods associated with macroalgae in Cabo Branco on the coast of the same state. The results of these studies show that mollusks need to be investigated further in many coastal regions of the country and require better alpha taxonomic and ecological knowledge.

Knowledge on malacofauna in coastal ecosystems of the state of Paraíba has become increasingly more accurate in recent years due to sampling efforts and studies conducted by local researchers (Duarte et al. 2014, 2015). However, several shallow-water habitats in the region require inventories to gain a better understanding of the diversity of marine invertebrates, mainly Mollusca, which is the second most diversified phylum in the world.

The families Veneridae and Littorinidae had the largest number of known species in the present study. In contrast, the families Neritidae, Columbellidae and Cerithiidae were recognized with only a single species, but as the most abundant mollusks in the study area. Other families (e.g., Solecurtidae, Crassatellidae, Myidae, Ellobiidae, Naticidae, Trochidae, Turbinellidae and Loliginidae) were also commonly represented by only a few specimens of a single species. In the present investigation, the number of species was similar to that found by Barroso et al. (2013). In both studies, six families of gastropods were recognized (Aplysiidae, Bullidae, Cerithiidae, Neritidae and Olivellidae, Turbinellidae), with a total of six species in common, and seven families of bivalves were found (Cardiidae, Donacidae, Lucinidae, Myidae, Solecurtidae, Tellinidae and Veneridae), represented by 10 species collected from both estuarine regions. The considerable difference in the composition between the two studies may be the result of factors such as state of conservation, sampling effort and environmental complexity. The study area in the present investigation is near a port and affected by both domestic sewage and industrial waste (Sassi 1991, Marcelino et al. 2005). In contrast, Grande Island is located in an estuarine complex with the best conserved mangrove areas in northeastern Brazil (Carlos et al. 2010, Barroso et al. 2013). Although not addressing the malacofauna of estuarine regions, other taxonomic studies (e.g., Longo et al. 2014, Tallarico et al. 2014, Duarte et al. 2014, 2015) report somewhat similar compositions and abundances for the taxonomic groups found in the present investigation.

There is an interesting diversity of feeding habits among the mollusks studied, especially when considering gastropods. All bivalve species identified are filter feeders (see Rios 2009). Cerithiidae and Neritidae are among the most abundant families of herbivorous caenogastropods sampled from coastal environments of Brazil (Rios 2009, Ourives et al. 2011, Duarte et al. 2014, Longo et al. 2014). Neritina virginea and Cerithium atratum were the most abundant herbivorous gastropods collected in the present study, both of which are commonly found associated with seagrass (see Longo et al. 2014, Duarte et al. 2015). On the other hand, neogastropods of the families Columbellidae, Melongenidae, Muricidae, Nassariidae and Olivellidae are among the main carnivorous and/or scavenger gastropod groups living in estuarine regions (Rios 2009, Ourives et al. 2011). Only one species of each family was found in the material studied, although these groups are usually more numerous in other Brazilian estuarine ecosystems (see Rios 2009, Ourives et al. 2011). The columbellid Parvanachis obesa was the most abundant neogastropod collected from the estuary of the Paraíba River. Ourives et al. (2011) identified six columbellids from Camamu Bay (in the state of Bahia), demonstrating that the species richness of this family is even greater in estuarine regions of northeastern Brazil. Although the present study does not allow an inference about potential anthropic impacts on mollusc diversity, there is likely a decline in species richness of the aforementioned families as a possible direct consequence of pollution and environmental changes in the region, making the invertebrate assemblage increasingly susceptible to a reduction of biodiversity.

The possible presence of an undescribed species of Epitoniidae in the study area will be investigated further. Microgastropods of this family are known to be free-living predators of other invertebrates or often living on stony and soft corals, hydroids, hydrocorals, discophores, siphonophores, gorgonians, zoanthids and sea anemones, feeding on living cnidarian tissues (Robertson 1963, 1970, Bouchet \& Warén 1986, Lima et al. 2012). More studies involving micromollusks of the estuary of the Paraíba River are needed, mainly considering the possibility of new species in the region.

Although widely distributed along the Brazilian coast, Calliostoma adspersum and Chicoreus brevifrons are the only species identified in this study that can be considered of uncommon occurrence in estuarine regions. The calliostomatid lives usually on muddy, sandy bottoms at depths of approximately $25 \mathrm{~m}$, while the muricid lives under rocks commonly feeding on barnacles and oysters (Rios 2009). Both species are reported herein for an estuarine area with many oyster beds, which is the preferred food of muricid gastropods (D'assaro 1966, Ponder 1998, Herbert et al. 2007, Rossato et al. 2014, Lima et al. 2016a). On the other hand, all species found are commonly distributed in estuarine ecosystems of Brazil, such as the bivalves Anomalocardia brasiliana and Iphigenia brasiliana, which have great economic importance to fishing communities. 
Coastal communities of invertebrates have been drastically affected by multiple anthropogenic impacts (Migotto \& Marques 2006). The fragmentation and destruction of habitats constitute the most serious threat to marine biodiversity (Gomes et al. 2000, Amaral \& Jablonski 2005, Migotto \& Marques 2006). The construction of shipyards causes profound changes in coastal habitats, directly and indirectly affecting the invertebrate assemblage. This habitat change disrupts the physicochemical environment, leading to the loss of local biodiversity. Furthermore, a number of chemical compounds and materials used in shipyard activities may have a significant impact on marine benthic fauna. Indeed, benthic invertebrates are efficient organisms for the evaluation and monitoring of such anthropogenic disturbances in coastal ecosystems (Chiarelli \& Roccheri 2014). Thus, surveys of benthic invertebrate assemblages in marine habitats, such as the estuarine region studied herein, are of fundamental importance to biomonitoring and the development of conservation strategies. Marine gastropods and bivalves have been successfully employed in environmental monitoring studies worldwide (Oehlmann \& Schulte-Oehlmann 2002). In many habitats, oysters and clams are the indicators most commonly used to reflect the impact of pollution/contamination (Oehlmann \& Schulte-Oehlmann 2002). Among the bivalves in the study area, Anomalocardia brasiliana, Crassostrea brasiliana, Iphigenia brasiliana, Macoma constricta and Tagelus plebeius are the main species with potential as bioindicators, especially of domestic, industrial and agricultural waste, due to their relatively large size, abundance, limited mobility (commonly sedentary/sessile as adults) and probably sensitivity to chemicals in the marine environment.

Thus, surveys of benthic invertebrate assemblages in marine habitats, such as the estuarine region studied herein, are of fundamental importance to biomonitoring and the development of conservation strategies.

\section{Acknowledgements}

The authors would like to thank M. Sc. Karlla Morgana (Real Consultoria e Soluções LTDA) for the logistical support and carrying out the field work in the estuary of the Paraíba River; Mr. Genilson C. Silva for helping in the field work; ecologists Paulinho Santana and Patrício Rocha (Universidade Federal de Sergipe) for helping with the photographs; Dr. Teodoro V. Júnior (Universidade Estadual Paulista Júlio de Mesquita Filho) for helping with the information on the cephalopod; Dr. Jéssica O. Prata (UFPB), Dr. Karla Paresque (Universidade Estadual de Campinas) and Dr. José Eriberto de Assis (UFPB) for sending their publications on invertebrates collected on the coast of Paraíba; Dr. Flávio D. Passos (Departamento de Biologia Animal, Universidade Estadual de Campinas, São Paulo, Brazil) and an anonymous reviewer for critically reviewing the manuscript.

\section{References}

AMARAL, A.C.Z. \& JABLONSKI, S. 2005. Conservação da biodiversidade marinha e costeira no Brasil. Megadiversidade. 1(1):43-51.

AMARAL, A.C.Z., RIZZO, A.E. \& ARRUDA, E.P. 2006. Manual de Identificação dos Invertebrados Marinhos da Região Sudeste-Sul do Brasil. Editora da Universidade de São Paulo, São Paulo.

AMARAL, A.C.Z., NALLIN, S.A.H., STEINER, T.M., FORRONI, T.O. \& GOMES, D.F. 2006-2012. Catálogo das espécies de Annelida Polychaeta do Brasil. http://www.ib.unicamp.br/museu_zoologia/files/lab_museu_zoologia/ Catalogo_Polychaeta_Amaral_et_al_2012.pdf (consultado em 07/06/2012).

ARAÚJO, P.G., MIRANDA, G.E.C. \& KANAGAWA, A.I. 2008. Repartição espacial da comunidade macrobêntica dos recifes da APA da Barra do Rio Mamanguape, Paraíba, Brasil. Rev. Nord. Biol. 19(1):29-50.

BARROS, J.C.N., SANTANA, C.A.S. \& LIMA, S.F.B. 2015. Three new species of Anacithara from the Southwestern Atlantic Ocean, Brazil (Neogastropoda: Conoidea: Horaiclavidae). Spixiana. 38(1):21-28.
BARROSO, C.X., RABAY, S.G., MEIRELLES, C.A.O. \& MATTHEWS-CASCON, H. 2013. Mollusks from two estuarine areas in Ceará State, northeastern Brazil, with new state records for four species. Check List. 9(3):504-509.

BOUCHET, P. \& WARÉN, A. 1986. Revision of the Northeast Atlantic bathyal and abyssal Aclididae, Eulimidae, Epitoniidae (Mollusca, Gastropoda). Boll. Malacol. Suppl. 2:299-576.

BRITO, R.J., DE ASSIS, J.E. \& CHRISTOFFERSEN, M.L. 2013. First record of Chaetacanthus magnificus (Polychaeta: Polynoidae) from the northeast coast of Brazil, with an overview of its taxonomic history. Research Journal of the Costa Rican Distance Education University. 5:25-32

CHIARELLI, R. \& ROCCHERI, M.C. 2014. Marine Invertebrates as Bioindicators of Heavy Metal Pollution. Open Journal of Metal, 4:93-106.

CUNHA, C.M., SANTOS, F.N. \& LIMA, S.F.B. 2016. New species of the genus Elachisina (Gastropoda: Elachisinidae) from northeastern Brazil. Zootaxa 4139(1):131-134. http://dx.doi.org/10.11646/zootaxa.4139.1.9

D’ASSARO, C.N. 1966. The Egg Capsules, Embryogenesis, and Early Organogenesis of a Common Oyster Predator, Thais Haemastoma Floridana (Gastropoda: Prosobranchia). Bull. Mar. Sci. 16(4):884-914.

DE ASSIS, J.E., SAMIGUEL, C.A., BRITO, R.J., CHRISTOFFERSEN, M.L. \& SANTOS, A.S. 2012. Polychaetous annelids from the coast of Paraíba state, Brazil. Rev. Nord. Biol. 21:3-44.

DUARTE, R.C.S., MOTA, E.L.S. \& DIAS, T.L.P. 2014. Mollusk fauna from shallowwater back reef habitats of Paraíba coast, Northeastern Brazil. Strombus. 21:15-29.

DUARTE, R.C.S., MOTA, E.L.S., ALMEIDA, I.C.S., PESSANHA, A.L.M., CHRISTOFFERSEN, M.L. \& DIAS, T.L.P. 2015. Gastropods associated to three reef macroalgae with different architectures. Strombus. 22(1-2):5-18.

FUKUDA, M.V., NOGUEIRA, J.M.M., PARESQUE, K. \& SAN MARTÍN, G. 2013. Species of Odontosyllis Claparède, 1863 (Annelida: Polychaeta: Syllidae) occurring along the Brazilian coast. Zootaxa. 3609(2):142-162. http://dx.doi. org/10.11646/zootaxa.3609.2.2

GOMES, A.S., PALMA, J.J.C., \& SILVA, C.G. (2000) Causas e conseqüências do impacto ambiental da exploração dos recursos minerais marinhos. Rev. Bras. Geof. 18(3):447-454.

HERBERT, G.S., MERLE, D. \& GALLARDO, C.S. 2007. A developmental perspective on evolutionary innovation in the radula of the predatory neogastropod family Muricidae. Am. Malacol. Bull. 23(1):17-32. doi: http:// dx.doi.org/10.4003/0740-2783-23.1.17

LIMA, S.F.B. \& CHRISTOFFERSEN, M.L. 2016. Redescription and designation of a neotype for Caecum floridanum (Littorinimorpha, Truncatelloidea, Caecidae) with a characterization of the protoconch and growth stages. ZooKeys. 585:17-31. doi: 10.3897/zookeys.585.7646

LIMA, S.F.B. \& GUIMARÃES, C.R.P. 2015. New bathyal Anachis (Neogastropoda: Buccinoidea: Columbellidae) from the Southwestern Atlantic, and the designation of a lectotype for A. stricta (Watson, 1882). Zootaxa. 3949(3):445-450. http:// dx.doi.org/10.11646/zootaxa.3949.3.10

LIMA, S.F.B., SANTOS, F.N. \& ABSALÃO, R.S. 2013. New Species of Caecum (Caenogastropoda: Rissooidea: Caecidae) from the Atlantic Coast of South America (Brazil) with a Description of the Protoconch and Growth Stages. Zool. Sci. 30(9):767-778. http://www.bioone.org/doi/full/10.2108/zsj.30.767

LIMA, S.F.B., QUEIROZ, V., OLIVEIRA, G.S.P., CHRISTOFFERSEN, M.L. \& GUIMARÃES, C.R.P. 2016a. Stramonita brasiliensis (Gastropoda: Muricidae) living as inquiline on the shell of Pugilina tupiniquim (Gastropoda: Melongenidae). Bull. Mar. Sci. 92(3):371-376. http://dx.doi.org/10.5343/bms.2016.1003

LIMA, S.F.B., JÚNIOR, I.C.L., GUIMARÃES, C.R.P. \& DOMINGUEZ, J.M.L. 2016b. New deep ocean Iravadiidae of the genus Ceratia (Caenogastropoda: Truncatelloidea) from an underwater canyon and adjacent regions of the southwestern Atlantic (northeastern Brazil). Zootaxa. 4066:183-188. http:// dx.doi.org/10.11646/zootaxa.4066.2.8

LIMA, S.F.B., GUIMARÃES, C.R.P. \& SIMONE, L.R.L. 2016c. Lepetella furuncula sp. nov. (Vetigastropoda: Lepetelloidea): the first species of the genus discovered in the South Atlantic Ocean (northeastern Brazil). Bull. Mar. Sci. 92:257-262. http://dx.doi.org/10.5343/bms.2015.1079

LIMA, S.F.B., CHRISTOFFERSEN, M.L., BARROS, J.C.N. \& FOLLY, M. 2012. Records and Descriptions of Epitoniidae (Orthogastropoda: Epitonioidea) from the Deep Sea off Northeastern Brazil and a Checklist of Epitonium and Opalia 
from the Atlantic Coast of South America. Int. J. Zool. Article ID 394381:1-12. http://dx.doi.org/10.1155/2012/394381

LIMA, S.F.B., QUEIROZ, V., BRAVO DE LAGUNA, I. H. \& MIOSO, R. 2014 New host for Dissodactylus crinitichelis (Decapoda, Pinnotheridae): First record of occurrence on Mellita quinquiesperforata (Echinodermata, Echinoidea) (Decapoda; Echinodermata). Spixiana. 37(1):61-68.

LOMÔNACO, C., SANTOS, A.S. \& CHRISTOFFERSEN, M.L. 2011. Effects of local hydrodynamic regime on the individual's size in intertidal Sabellaria (Annelida: Polychaeta: Sabellariidae) and associated fauna at Cabo Branco beach, north-east Brazil. Mar. Biod. Rec. 4:e76. http://dx.doi.org/10.1017/ S1755267211000807

LONGO P.A.S., FERNANDES M.C., LEITE F.P.P. \& PASSOS F.D. 2014. Gastropoda (Mollusca) associated to Sargassum sp. beds in São Sebastião Channel - São Paulo, Brazil. Biota Neotrop. 14(4):1-10.

LUCENA, R.A., ARAÚJO, J.P. \& CHRISTOFFERSEN, M.L. 2015. A new species of Anoplodactylus (Pycnogonida: Phoxichilidiidae) from Brazil, with a case of gynandromorphism in Anoplodactylus eroticus Stock, 1968. Zootaxa. 4000:428-444. http://dx.doi.org/10.11646/zootaxa.4000.4.2

MARCELINO, R.L., SASSI, R., CORDEIRO, T.A. \& COSTA, C.F. 2005. Uma abordagem sócio-econômica e sócio-ambiental dos pescadores artesanais e outros usuários ribeirinhos do Estuário do Rio Paraíba do Norte, estado da Paraíba. Trop. Oceanogr. 33:183-197.

MEDEIROS, C.R., HEPP, L.U., PATRÍCIO, J. \& MOLOZZI, J. 2016. Tropical Estuarine Macrobenthic Communities Are Structured by Turnover Rather than Nestedness. PLoS ONE. 11(9):e0161082. doi:10.1371/journal.pone.0161082

MELO, R.S., CRISPIM, M.C., LIMA, E.R.V. \& NISHIDA, A.K. 2006. Estimativa da capacidade de carga recreativa dos ambientes recifais da Praia do Seixas (Paraíba - Brasil). Turismo - Visão e Ação. 8(3):411-422.

MIGOTTO, A.E. \& MARQUES, A.C. 2006. Invertebrados marinhos. In Avaliação do estado do conhecimento biodiversidade brasileira (L. Thomas, ed.). Ministério do Meio Ambiente, Brasília, v. 1, p. 149-202.

MMA, 2010. Gerência de Biodiversidade Aquática e Recursos Pesqueiros. Panorama da conservação dos ecossistemas costeiros e marinhos no Brasil. MMA/SBF/ GBA, Brasília.

OEHLMANN, J. \& SCHULTE-OEHLMANN, U. 2002. Chapter 17: Molluscs as bioindicators. In Bioindicators \& Biomonitors: Principles, Concepts and Applications (B.A. Markert, A.M. Breure \& H.G. Zechmeister, eds). Eselvier Science B.V., Amsterdam, v. 6, p. 577-635.

OURIVES, T.M.S., GUERRAZZI, M.C. \& SIMONE, L.R.L. 2011. Gastropods from Camamu Bay, state of Bahia, Brazil. Check List. 7(3):328-336.

PARESQUE, K. \& NOGUEIRA, J.M.M. 2014. The genus Haplosyllis Langerhans, 1879 (Polychaeta: Syllidae) from northeastern Brazil, with descriptions of two new species. Mar. Biol. Res. 10(6):554-576. http://dx.doi.org/10.1080/1745 1000.2013 .841941

PARESQUE, K., FUKUDA, M.V. \& NOGUEIRA, J.M.M. 2014. The genus Exogone (Polychaeta: Syllidae) from the Brazilian coast, with the description of a new species. Zootaxa. 3790(4):501-533. http://dx.doi.org/10.11646/zootaxa.3790.4.1

PARESQUE, K., FUKUDA, M.V. \& NOGUEIRA, J.M.M. 2016. Branchiosyllis, Haplosyllis, Opisthosyllis and Trypanosyllis (Annelida: Syllidae) from Brazil, with the Description of Two New Species. PLoS ONE. 11(5):e0153442. doi:10.1371/journal.pone.0153442
PONDER, W.F. 1998. Family Muricidae. In Mollusca: The Southern Synthesis. Fauna of Australia (P.L. Beesley, G.J.B. Ross \& A. Wells, eds). CSIRO Publishing, Melbourne, v. 5, p. 820-824.

PRATA, J., MANSO, C.L.C. \& CHRISTOFFERSEN, M.L. 2014. Aspidochirotida (Echinodermata: Holothuroidea) from the northeast coast of Brazil. Zootaxa 3889(1):127-150. http://dx.doi.org/10.11646/zootaxa.3889.1.8

QUEIROZ, V., SALES, L.O., SAMPAIO, C.L.S., NEVES, E.G. \& JOHNSSON R. 2011. Gastropoda, Caenogastropoda, Eulimidae, Annulobalcis aurisflamma Simone and Martins, 1995: First record to northeastern Brazil. Check List. $7: 645-647$.

QUEIROZ, V., SOUZA, L.S., PIMENTA, A.D. \& CUNHA, C.M. 2013. New host records to Melanella (Caenogastropoda: Eulimidae) from the Brazilian coast. Mar. Biodivers. Rec. 6:1-5.

REDFERN, C. 2013. Bahamian seashells: 1161 Species from Abaco, Bahamas. BahamianSeashells.com, Inc., Florida

RIOS, E.C. 2009. Compendium of Brazilian Sea Shells. Evangraf, Rio Grande, RS

ROBERTSON, R. 1963. Wentletraps (Epitoniidae) feeding on sea anemones and corals. Proc. Malacol. Soc. Lond. 35(2-3):51-63.

ROBERTSON, R. 1970. Review of the predators and parasites of stony corals, with special reference to symbiotic prosobranch gastropods. Pac. Sci. 24:43-54.

ROSSATO, M., CASTRO, I.B. \& PINHO, G.L.L. 2014. Imposex in Stramonita haemastoma: a preliminary comparison between waterborne and dietborne exposure. Ecotoxicol. Environ. Contam. 9(1):87-92. http://dx.doi.org/10.5132/ eec.2014.01.011

SANTOS, A.S., BRASIL, A.C.S. \& CHRISTOFFERSEN, M.L. 2014. Sabellaria and Lygdamis (Polychaeta: Sabellariidae) from reefs off northeastern Brazil including a new species of Sabellaria. Zootaxa. 3881:125-144. http://dx.doi org/10.11646/zootaxa.3881.2.2

SANTOS, A. S., NOGUEIRA, J.M.M., FUKUDA, M.V. \& CHRISTOFFERSEN, M.L. 2010. New terebellids (Polychaeta: Terebellidae) from northeastern Brazil. Zootaxa. 2389:1-46.

SASSI, R. 1991. Phytoplankton and environmental factors in the Paraíba do Norte River Estuary, northeastern Brazil: composition, distribution and quantitative remarks. Bolm. Inst. oceanogr. 39(2):93-115.

TALLARICO, L.F., PASSOS, F.D., MACHADO, F.M., CAMPOS, A., RECCOPIMENTEL, S.M. \& INTROÍNI, G.O. 2014. Bivalves of the São Sebastião Channel, north coast of the São Paulo State, Brazil. Check List. 10(1):97-105.

TUNNELL, Jr.J.W., ANDREWS, J., BARRERA, N.C. \& MORETZSOHN, F. 2010. Encyclopedia of Texas Seashells: Identification, Ecology, Distribution and History. College Station, Texas A \& M University Press, Texas.

WoRMS. 2016. Mollusca. Accessed through: World Register of Marine Species at http://www.marinespecies.org/aphia.php? $\mathrm{p}=$ taxdetails\&id=51 ((last access in $05 / 05 / 2016$ ). 